Fecha de recepción: noviembre 2012 Fecha de aceptación: mayo 2013 Versión final: junio 2014

\section{Achieving the new graduate dream: building sustainable business success at a small scale}

Aaron Fry ${ }^{\star}$, Steven Faerm ${ }^{\star *}$ y Reina Arakji ${ }^{\star * *}$

\begin{abstract}
Summary: Fashion graduates are increasingly electing to direct their professional ambitions towards small business entrepreneurship rather than traditional corporate modes of practice. These fashion entrepreneurs must engage with business development and management, skills that are normally not required of designers within the corporate business model. How can the fashion entrepreneur of the future be prepared? What knowledge and skills are required for becoming a fashion entrepreneur? Is there a disconnect between what graduating fashion entrepreneurs think they need to know, and the practices that will actually best prepare them for starting and maintaining a fashion design start-up business? The authors summarize fashion entrepreneurship in New York City, discuss the logistics of the globalized mass-market, and the current challenges in fashion design pedagogy with regard to preparation for this global fashion context. The authors then highlight the counter-trend of the small-scale local venture. Finally they propose broad strategies directed toward the fashion entrepreneur who wishes to create a sustainable small-scale fashion business venture in New York
\end{abstract}

Keywords: creative entrepreneurship - fashion and business - fashion and sustainability - fashion business strategy - fashion entrepreneurship - fashion pedagogy - incidental entrepreneur.

[Summaries in spanish and portuguese at page 175]

${ }^{(*)}$ Associate Professor of Design Strategies at Parsons, The New School for Design in New York City since 2005. Aaron is an artist, designer, educator and researcher with eighteen years experience in the design education field, having previously taught full-time at three universities, two in his native country of New Zealand, and, prior to Parsons, at Massachusetts College of Art in Boston between 1999 and 2005. Current research includes being co-director of the Visualizing Finance Lab (VFL), a School of Design Strategies research laboratory that explores the relationship between narrative illustration and financial concepts in journalism, popular culture, design, pedagogy and in personal finance (financial literacy) policy. Aaron holds a BFA from Elam School of Fine Arts, University of Auckland, a Graduate Diploma in Art from Sydney College of the Arts, Sydney University and an MFA from the University of Hawaii at Manoa. [See full version at page 208]

${ }^{(*)}$ Parsons alumnus ('94), Steven began teaching in 1998. Currently is an Assistant Professor in the Parsons BFA Fashion Design Program and served as its Program Director 
from 2007-2011. He completed his M.S. Ed. at Bank Street College of Education and plans to pursue $\mathrm{PhD}$ studies in Education. [See full version at page 207]

${ }^{(* *)}$ Assistant Professor of Strategic Management and Design at the School of Design Strategies, Parsons the New School for Design as well as a founding member of the Enterprising Design Lab. Reina's academic background includes a PhD in Information Systems from The City University of New York - Graduate Center, and an MBA in Finance and a BA in Economics from the American University of Beirut, Lebanon. [See full version at page 207]

\section{Introduction}

The "trial by fire" that fashion entrepreneurs face when launching their own label is not so different from the tribulations faced by entrepreneurs in other professions. The demand for knowledge when beginning one's own company helps to support an industry that provides literature to prospective business owners. Much of this business literature is devoted to advice from invariably successful "self made" entrepreneurs. An example of this type of business advice is Sir Richard Branson's book Like a Virgin (2012) which promises "advice on setting up one's own company, improving career prospects, or developing one's leadership skills."

Publications of this sort typically claim to contradict traditional business school wisdom and substitute it with anecdote-laden advice that ranges from pitching your idea to strategic decision-making and working with established corporate partners. Much of the advice provided is derived from hindsight (i.e. getting it wrong and learning from mistakes made and then extrapolating these mistakes into principles through inference). This literature tends to reinforce the mythology that the degree of the entrepreneurs' perseverance correlates with success; it consistently underestimates the role of luck, existing capital base, and/or personal connections as prerequisites for the story's happy ending, because clearly these types of narratives do not a best-seller make. Therefore, the overarching subtext of self-help business books is the notion that "trials by fire" are an essential ingredient of business entrepreneurship; a part of the entrepreneur's difficult but necessary rite of passage to the promised land of entrepreneurial success.

As professors in art and design at Parsons The New School for Design in New York City, we engage with a diverse student cohort who will enter an increasingly complex professional landscape; some students wish to enter large design corporations or "houses" but an increasing number are choosing to begin their own small-scale business ventures directly upon graduation. Given the nature of this volatile industry-and the fragility of the American economy- we question the value of much of the self-help business advice to emerging design graduates. In this paper we focus attention on the issues that we hear directly from start-up entrepreneurs rather than from the (already successful) incumbents. We ask entrepreneurs about the factors that have helped sustain the fashion brand(s) that they have launched and we check this against the experience of established players and the business literature. 
In parts I to IV of this paper, we provide a context for small fashion businesses at the local level by investigating the New York Fashion Industry. We then discuss the consumer-led demand for high design at mass-market prices and explore the rise of H\&M, Zara, and other huge volume labels; a phenomenon we return to later in the context of designer collaborations. We then discuss key questions in the preparation of undergraduate fashion design students at Parsons through the lens of the traditional (Bauhaus) design education model and how this responds to the challenges of the globalized fashion industry and the counter-trend of locally based entrepreneurship. Finally, we create an avatar; an archetype that we call the Incidental Fashion Entrepreneur (IFE) in order to better understand the underlying motivations for young fashion designers who elect to become small business entrepreneurs.

In parts $\mathrm{V}$ to IX we provide a summative overview of the key themes that emerged from the research obtained through our online survey, focus group, interviews, and literature review. These themes include scalability and the role of luck, and the capacity of social media as a means of creating a tipping point that can lead to exponential growth. We then discuss social entrepreneurship as a business strategy, and opportunities through design collaborations. On the more pragmatic front, we introduce strategies that may support financial sustainability, including the creation of cash drivers, achieving mass-market access as a boutique brand, minimizing overhead, and leveraging relationships based on labor-sharing. Finally, we discuss the fundamental importance of understanding market segmentation, relating this to implicit attitudes that may inhibit start-up entrepreneurs from working from a business plan alongside the development of their design vision.

\section{The New York fashion industry}

The New York Fashion Industry assumed prominence internationally following World War II. During the war, Parisian fashion suddenly became unavailable and American women simultaneously began to demand easy, "off the rack" creations in keeping with their new (less homebound) role(s) in the war effort. From the design side, this trend was spearheaded by Claire McCardell, Norman Norell, and Bill Blass, among many others. The garment industry eventually grew into the single largest employer in New York City (Pinkerson \& Levin, 2009) and the high demand for skilled laborers led to the creation of New York City's Fashion Institute of Technology (FIT) in 1944.

Today, New York City has more fashion establishments than anywhere else in the United States (The Municipal Art Society of New York [MASNY], 2011). New York's success as an incubator and attracter of fashion design houses is evidenced by the over 270 fashion presentations that were held during New York Fashion Week in February of 2012. This event was attended by over 100,000 fashion industry professionals (Berry, 2012). As recently as 2010, the New York fashion industry accounted for $4.6 \%$ of the country's total fashion employment; this figure is almost equal to finance, in which New York City accounts for 5.6\% of the nation's financial services jobs (MASNY, 2011). It is evident from these statistics that the fashion industry is vital to New York City's economy. 
The Fashion Industry contributes to the City indirectly in a variety of ways through such industries as finance, marketing, merchandising, advertising, photography, higher education, the performing arts, and tourism. The fashion industry serves as an "engine" for this larger "creative economy" that generates $\$ 9$ billion in total wages citywide, and produces total sales that are estimated at $\$ 55.6$ billion per year, with the resulting designs being displayed in approximately 5,000 designers' showrooms (MASNY, 2011). Further, in 2012, the financial impact of New York's Fashion Week (held in February and September) was a net of approximately $\$ 466$ million in direct visitor spending leading to a further $\$ 773$ million in economic impact.

Despite these significant numbers, the City's historic "garment center" (based in midtown Manhattan) has been radically reduced in recent decades. The percentage of clothing made in the USA has declined from 95\% in 1965 to just 5\% in 2009 (Pinkerson \& Levin, 2009). Around the world, traditional fashion production centers, such as those in Milan, are being vacated due to the availability of less expensive production facilities overseas (Gill, 2008). This is a salient issue for the emerging designer who must rely upon local manufacturing due to the expensive costs - and typically exorbitant production minimums-when producing with overseas factories. In an effort to retain local production capacity the Save The Garment Center (STGC) movement was initiated in 2007 by factory owners in response to New York's City Hall to lift the 1987 zoning laws that had protected tenants' leases and offered local talent production facilities. As a trade association, STGC aims to "support factories, suppliers and designers through education and advocacy" (Save the Garment Center, 2012).

\section{Consumers and consumerism}

A significant trend in American consumer culture is the increased importance placed on aesthetics and on the way in which the "designed" object has assumed an increasingly important role in the marketing of all products (Postrel, 2003). The demand for aesthetically appealing design is reflected in the success of such mundane objects as waste baskets; Karim Rashid's Garbo collection of waste baskets for Umbra has sold 2.7 million units (Postrel, 2003). Rashid has also designed a manhole cover for Con Edison.

The entry of design into the museum can be seen in numerous instances, with two examples being the sneaker exhibition at The San Francisco Museum of Art and the Giorgio Armani retrospective at New York City's Guggenheim Museum. As Postrel notes:

Aesthetics is more pervasive than it used to be-not restricted to a social, economic, or artistic elite, limited to only a few settings or industries, or designed to communicate only power, influence or wealth. Sensory appeals are everywhere, they are increasingly personalized, and they are intensifying. (Postrel, 2003, p. 5). 
The globalization of design-driven consumption is underscored by the proliferation of fashion shows in the urban centers of India, Buenos Aires, and Australia that are "state sponsored and therefore represent the commercial and cultural interests of the respective country" (Loschek \& Klose, 2008).

From the consumer side, design-oriented businesses have made their products increasingly accessible to the mass-market in order to meet the new middle class obsession with design. Retailers Target, Hennes \& Mauritz (H\&M), and Kohl's have all offered "guest star" collections by such top designers such as Karl Largerfeld, Vera Wang, Isaac Mizrahi, and Comme des Garçons with great success (Pink, 2005). This parallels a generally sharper rise in the demand for fashion; the average person now consumes roughly four times the number of clothes they did in 1980, and spends at least 625 British Pounds (approximately $\$ 1,000$ USD) a year on clothes, on average. (Siegel, 2011)

In order to meet this increased demand, retailers operate with unprecedented speed. H\&M's lead time, from design-to-retail, is just three weeks (Siegel, 2011) and sells more than 500 million items every year, both online and from over 1,700 stores (Leonard, 2010). The Spanish retailer Zara employs 200 designers who design 40,000 styles each year, of which 12,000 are produced (Siegel, 2011). This dizzying volume and variety has led some retailers to offer up to 26 fashion "seasons," which means that each "season" lasts just 2 weeks (Leonard, 2010).

Everything is instant gratification, this is a [fashion] response to it, demand is high and few have any knowledge of clothes, there is a low value for wellmade clothes, it's ok, it's there. So I have to work around it, and with it. Fast fashion. When I worked in corporate I was designing eight collections per year, with no time to think as a creative, and that's one reason why I left. You just have to change the floor to bring the customer in every day, with variety. The floor is designed by the merchandiser by square feet, it's part of marketing to get good numbers for the board meetings. (Designer X)

The globalization of the fashion industry that once worked within localized and specific Garment Centers, the sharp increase in consumer demand for innovative and new product, and technologies that allow for expedited garment manufacturing areas are altering how fashion brands will operate and compete in the future marketplace. These changes will, in turn, greatly impact the role of the fashion designer in this accelerated market, and will thus contribute to the evolution of design education.

\section{Recent developments in fashion design education}

What is the current state of design education, and how have pedagogical practices evolved to better prepare graduates for shifts in the industry and new patterns of consumerism? What will be the dominant pedagogic philosophies adopted by fashion design educators? What types of preparation will future fashion entrepreneurs require in order to sustain a 
small business venture?

In contrast to the Bauhaus design education model that emphasized learning through making, today's design pedagogy is evolving due to the fashion industry's unprecedented rates of consumer demand and consumption. Fashion educators are questioning the attributes and skills that will be needed by future graduates if they are to successfully enter this accelerated and distributed fashion industry. This unpredictable scenario is largely due to the phenomenon of globalization; in today's design room, a designer might hail from Belgium, design for a German brand, present work bi-annually in Milan, and sell to stores in Asia, as was the case of Raf Simmons who designed for the label Jil Sander. It is therefore necessary for fashion designers to become increasingly educated in the nuances of the expanding global markets, sub-cultures, available (and distributed) resources, technologies, communication strategies, management of distributed enterprises, and global supply and value chains.

At the other end of the industry spectrum is the "local" movement, which has formed partly as a response to this hyper-globalization and an increasing realization that it is socially and environmentally unsustainable in its current form. In New York City, aspects of this movement-in-formation can seen in neighborhoods such as Greenpoint and Williamsburg, both located in Brooklyn, New York City. These communities are home to a myriad of self owned and operated stores which sell products from local talent. Collectively this movement enjoys sustained success; in 2010 the "Small Business Saturday" campaign that falls on the Saturday after the Thanksgiving Holiday was launched. This one day event generated $\$ 5.5$ billion with independent merchants and garnered 3.2 million "likes" on Facebook. The added value that can accrue to locally produced food, clothing, and other artifacts is evidenced by the rise of Farmer's Markets in all parts of the city. The reaction against large, global conglomerates and the attraction toward locally produced and distributed food, craft and design, is significant.

A fusion of knowledge derived from both of these paradigms -the global and the local perspectives- may provide significant opportunities for the start-up designer. An understanding of global value chains (the value of distributed expertise) with a strong project management focus can help a designer scale up and outsource deficits in skill or expertise. At the same time, a deep awareness of the specific tastes of local communities and the attraction that uniquely local products have globally may help a designer to access a broader marketplace while creating a tailored product for the specific location.

How do these paradigms reconcile in the classroom? Together with globalization, and the complexities that working in this context entails, the exodus of traditional production centers from urban design centers now puts pressure on fashion designers to conform to a system they are likely not completely prepared for; they must increasingly become knowledge workers in addition to hands-on clothing production experts. The success of this knowledge-based economy will rely on future designers who will acquire success "not simply by how smart they are by studying traditional subjects or to those who have master technical skills. It will go to those who are able to comprehend both the problem and the context of the problem and how to design or create solutions that are efficiently and aesthetically desirable for the community" (Van Zandt, 2011). As designer Clement Mok (Pink, 2005) states: 
The next 10 years will require people to think and work across boundaries into new zones that are totally different from their areas of expertise. They will not only have to cross those boundaries, but they will also have to identify opportunities and make connections between them ( $\mathrm{p} 135$ ).

The challenge then is to teach students the skills they need to excel in the marketplace while giving them the knowledge they need to remake that very marketplace (Towers, 2005). Reconciling the global with the local will require the designers of the future to operate strategically in this space. This idea is in keeping with those who assert the designer is underequipped because many schools around the world are teaching fashion design as a creative process only, and not as an enterprise; the few business courses taught within fashion design programs are marginalized, if offered to students at all. However, the fashion graduate's desire for such knowledge is evidenced through a Parsons survey (2010) in which the top suggestions for job preparation from undergraduate students were: Training in entrepreneurship (45\%), practical knowledge of how the workplace/ industry function (42\%), and portfolio development and presentation (39\%); for the past two years more in-depth industry knowledge and training in business skills were cited as the top two suggestions for Parsons to better prepare graduates entering the job market.

I've worked 9 internships in 8 different companies. No other company/ experience has taught me what my current position at a small firm can and is teaching. Every day is a new task. Problem solving, taking initiative, filling the void for [the] need of more employees. It's terrifying and rewarding ten times over. Please urge more students turned interns to experience the smaller company and LEARN. (Survey respondent)

A significant challenge when educating future fashion entrepreneurs is to achieve a successful balance between business education and design creativity. For some, the solution may not be to teach fashion students the business of fashion but to help them to locate the right partner or team, just as Yves Saint Laurent collaborated with Pierre Berger, Tom Ford collaborated with Domenico De Sole, Calvin Klein collaborated with Barry Schwartz, and so on. Whichever philosophies or models are adopted, many assert that designers must still respect and understand that fashion is as much of a business as an art and this requires an awareness of how fashion, as a business, works.

\section{The Incidental Fashion Entrepreneur (IFE)}

What inspires fashion entrepreneurship? Fashion design students and start-up designers frequently hold attitudes about the fashion industry -and perhaps about their lives generally- that exert a powerful influence on their professional existence. These beliefs form a designer's "background," a (usually unspoken) set of orientations about what kind of designer (or person) they are. These orientations may not be completely understood 
by the design entrepreneur themselves, yet they tend to delimit the array of possibilities within their design and business undertakings. For example, if statements such as "I'll never be that kind of designer," or "that's just not the type of thing I'd ever do" are part of a designer's phraseology, then the designer possesses a "background" that may be essential to his or her design identity and will therefore exert a profound influence on her decisionmaking and career path.

In education, pedagogy has a large influence over how students form this background, starting with how they perceive themselves and their professional goals. For example, fashion design students commonly subscribe to the notion that the high-end design market is the most prestigious professional goal attainable. Within academic programs that emphasize conceptual and avant-garde fashion -which typically serves a significantly smaller audience than the mass-market- the future designer may adopt a blindness towards alternate professional pathways by assuming there is a lack of creativity at large, corporate companies.

In the course of our research, students and entrepreneurs expressed the need to start their own company in order to achieve the creative satisfaction they desire. In fact, virtually all of the respondents became fashion entrepreneurs as a consequence of their desire to "say something" through their design. Similarly, others believed a small business would offer them the ability to "do things on [their] own terms" (unlike in the corporate world).

I am an artist and fashion design is my medium. I need to feel creative and successful under my own terms [as a small business owner]. This has been proven to me by my projects outside of my mass-market day job. Also, I have more power to change the landscape of the antiquated fashion design formula that most established companies follow. I'm ready to take on the responsibility to manifest my vision now, and make a difference now. (Survey respondent)

Although the smaller high-end fashion market may provide certain creative freedoms not found in larger corporations, there are many challenges lamented by entrepreneurs, particularly regarding financial commitments and attendant stress. These high-end designers have elected to focus on a very small "niche within a niche" market that is highly competitive. Despite their familiarity with the relative job security and benefits found at larger corporations, the prestige associated by working in high-end design inspired these designers to focus on this particular market segment.

[Owning my own business] allows me to continue to blossom my creativity and passion that kept me driven during school [sic]. It also allows me to design without a "filter" since it is completely my aesthetic, not through the eyes of another designer. (Survey respondent)

Due to this strong desire for personal satisfaction through design creativity, many entrepreneurs launch businesses as a consequence of their pursuit of this passion; the motivation frequently having nothing to do with business itself. This creates a focus 
on design utility rather than business utility, and in certain instances these functions may be in conflict with one another. When asked why they started their own business -a momentous and risky decision - the majority of respondents were vague about the exact reasons for their decision, beyond creative autonomy, which rates as a very strong motivation in our respondents. The same uncertain motivation also exists amongst experienced entrepreneurs who have (perhaps) inadequately considered the objectives and consequences of their involvement in an entrepreneurial venture. However, these emerging business owners, or Incidental Fashion Entrepreneurs (IFE) can, when pressed, state with great articulation and animation what their fundamental position is about design and to some degree, by extension, about business.

A prerequisite of entrepreneurship is naiveté because if you know how daunting the task is in front of you, you wouldn't do it. There's a blessing in not knowing what you don't know [and] it's a precondition to being an entrepreneur. I don't find entrepreneurs are those who really know it otherwise they go the other route. (Designer Y)

\section{Methodology}

Why are design graduates increasingly electing to direct their professional ambitions towards smaller business models, rather than larger and traditional corporations? What are the skill-sets required, and what do young entrepreneurs truly need to know? What factors may help sustain entrepreneurial success for emerging fashion designers? Three levels of design professional were engaged in this study; with each group, a qualitative approach was used in order to distill selected insights into the study's findings. The research methods included:

- An online survey was developed and sent to over 500 Parsons alumni who graduated from the BFA Fashion Design program at Parsons between 2007 and 2012. These designers had diverse professional experiences across the fashion industry. Data about their academic preparation at Parsons, internship experiences, their design and business skill-sets, and their professional goals was collected.

- A focus group comprising of eight design professionals who graduated from Parsons between 2006 and 2008 was conducted. All participants worked in New York City. Four participants were small-scale entrepreneurs, and four worked in large fashion companies. The groups' opinions and observations about small business entrepreneurship and careers at larger fashion houses were collected.

- Interviews with two experienced industry professionals were conducted. "Designer X" was a former designer for a large brand who left to become the creative partner of his own menswear label. "Designer Y" left his own label after nine years to work as a 
marketing director for a multinational company that provides specialized legal, business, and other services to established fashion brands. The professionals' opinions and observations about the benefits and challenges of fashion entrepreneurship, changes in the fashion industry's economic and cultural climate, and their experiences in launching and running a small-scale practice were collected.

The themes that we identified in sections V through IX are by no means an exhaustive account of all the issues that design entrepreneur face. It is not a practical "how-to" guide to be read when scouting real estate, finding partners etc. These themes emerged through the conversations and survey data, but there are other issues we would like to have dealt with in more depth which we identify in the conclusion.

\section{The dynamics of scalability and "being in the right place at the right time"}

Young designers often overlook the fact that the success of a fashion brand is achieved through either "fashion opinion leadership" or "fashion innovativeness" (Polegato \& Wall, 1980). Young designers overwhelmingly attempt to achieve "fashion opinion leadership," which involves expressing new designs that positively influence customer purchases; they largely ignore "fashion innovativeness" in products (e.g. specialized fabrics, smart clothing, etc.) and business operations (e.g. business model and industrial partnerships, marketing and finance, etc.) (Yu, Fan, Harlock, \& Ng, 2006).

While we agree that fashion opinion leadership is partially achieved through new design, in a media-driven globalized context it can also be substantially achieved through wordof-mouth endorsement from fashion opinion leaders as the following example illustrates:

Thirteen years ago on a flight from Miami, Lazaro Hernandez noticed Vogue editor Anna Wintour on the same flight that he was on. He asked the stewardess to pass Wintour a note on a napkin on which he'd written a note about himself, his love of fashion, and his admiration for her. Several weeks later Hernandez received a call from Michael Kors' office with the message that "Anna Wintour says you should work here," and he did. (Larocca, 2003)

In 2001, Jack McCollough and Lazaro Hernandez presented their senior year collection at Thesis Review Week in the Parsons Fashion Design Program. At this particular session one of over a dozen that week- Barney's Fashion Director Julie Gilhardt sat on the jury. In a never-before-seen gesture, Hernandez and McCollough received a buying order on the spot from Ms. Gilhardt, thus launching their brand Proenza Schouler.

Nearly thirteen years and many accolades later from both press and retailers alike, the Valentino Fashion Group, owned by Premira, bought a 45\% stake in the Proenza Schouler, enabling the brand to grow significantly; in 2011 the brand was recapitalized through a 
further sale of Permira's stake to a group of investors that includes Theory founder Andrew Rosen. For hundreds of emerging designers this is the ultimate dream, yet the wide divide between the few successful and many struggling designers is considerable. Cinderella stories such as this cannot be planned, yet these "lucky breaks" can be the making of a start-up designer. We have not encountered a book on how to be lucky, although there are case studies about the role of luck and much business literature that conflates luck with strategy. In this paper, the authors consider the environment (of scalable, or power laws) in which lucky breaks can occur.

Nassim Nicholas Taleb has studied probability and risk in its many forms. He describes the phenomenon of scalability as a "winner-take-all" scenario in which the distinction between the winner and numerous "runners up" is significant. According to Taleb, scalability is an evolutionary process in which the successful DNA or species will reproduce itself, and the unsuccessful will simply vanish. This is particularly prevalent in the design professions because they are socially influenced, brand-driven, and heavily globalized; all of these factors drive scalability.

In a globalized fashion system, a designer can separate intellectual work (e.g. the design, marketing strategy, and business planning) from the making of the garment or accessory. Intellectual property- such as design and business strategy -are highly reproducible and thus highly scalable. While it is true that garment making (or fabrication) can be scaled, this is only achieved through significantly increased labor and material resources (capital investment). In contrast, the best-selling author J.K Rowling only needs to write a single copy of a Harry Potter book to be able to sell millions of copies. The same holds true for items such as an Hermes scarf or a Prada bag; the significant payoffs in the global economy are achieved through scaling. In the design field, what is considered "talent" often comes from the brand's perceived success (Taleb, 2007, p. 31). "Accumulated advantage," is a term coined by the sociologist Robert K. Merton and it describes the Proenza Schouler story well; it is the process by which, once initial success has been achieved (often attributable to luck), additional advantages accrue that are based on this initial "lucky break." If luck leads to accumulated advantage, which then allows a designer to "scale-up" his or her emerging business, the winner really can take very large quantities of market share very quickly.

I'll be brutally honest. It makes no sense to start a fashion brand unless you have tons of money, or celebrity. I advise everyone not to [open their own fashion brand]. (Designer X)

The quote above demonstrates the power of accumulated advantage. It accounts for nondesigner celebrities having to become "designers" (and owners) of successful brands; initial success leads to further successes. It is instructive that the design and the brand are two very different things, and it is important for designers to recognize the difference. For example, Alan Millstein, Editor of The Fashion Network Report, described the components of American brand Tommy Hilfiger's success by stating: "It's a combination of great marketing, merchandising, and hype. He's packaged better than any designer since Ralph 
Lauren... Tommy will never be on the designer rack, but he's powerful enough to have become a brand name. That's what every designer really wants to be." Hilfiger understands the difference between designers and "brands."

Unsurprisingly, social influence has been shown to drive popularity; the most liked items- particularly those championed by opinion leaders become the most popular items, and the tipping point can be a very small event or a very slight preference; if one object happens to be slightly more popular than another at just the right point it will tend to become more popular still. As a result, "even tiny, random fluctuations can blow up; generating potentially enormous long-run differences among even indistinguishable competitors" (Watts, 2007).

Social influence has also proven to increase the level of unpredictability. In one research study, a large number of participants were separated into eight different artificial "worlds," or social groups, and were uniformly influenced by who-liked-what. The participants then nominated their most and least favorite items accordingly. Interestingly, each group had a completely different set of winners and losers. Social influence was domain specific, but did not apply across domains where information was not shared (Salganik, Dodds, \& Watts, 2006). However in a media-saturated world, information is shared. This globalized media teams up with branding to exponentially expand -or scale-up- a social domain or "world;" teenagers now wear the same branded Abercrombie and Fitch $\mathrm{t}$-shirts on warm summer nights in Des Moines, Iowa and in the Rocina favela in Rio de Janeiro, Brazil.

Scaled-up domains produce "towering figures" in such areas as fashion design and publishing. In the globalized fashion industry, the opinion leader of reference is Anna Wintour, Editor in Chief of Vogue magazine. The precipitant success of Rodarte and Proenza Schouler both involved Wintour's "discovery" of these emerging designers by fortuitous means. The subsequent elevation in the value of their brands is attributable to accumulated advantage. Similar "discoveries" and accumulated advantages have involved celebrities selecting emerging designers to wear at the "right" events and thus garnering extensive publicity through the media. For example, Isabel Toledo, who began showing her fashions in 1985, was considered a relatively "unknown" designer prior to Michelle Obama wearing the designer's clothes to President Barack Obama’s 2009 inauguration.

In what ways can small-scale fashion entrepreneurs apply this knowledge and potentially increase their brand's growth? For young designers, it is important to be skeptical of what is heard; successful business consultants have a tendency to underestimate the role of luck -or the random event- and to overestimate the role of personal agency in their professional rise. Respondents in this study generally agreed that luck can be a powerful game-changer. Luck is, by definition, unpredictable and therefore cannot be a part of any planning process. Instead, start-up fashion entrepreneurs should invest in opportunities that garner maximize exposure and put themselves into the locations in which social interaction leads to opportunities. This investment will increase situations for random, 
possibly lucky, game-changing events. Today's entrepreneurs may be able to "look bigger" (and more successful), creating a "tipping point" through strategic use of social media; a subject we'd like to address in a future study.

\section{Social entrepreneurship and the new collaborators}

\section{Social entrepreneurship}

[It's] about interpersonal relationships, I learned how to be polite but firm, how to get what you want, with the least amount of money. I didn't deal with these things at a big company, I was a king, everyone was coming to me, because the units were so big, and it's a good company name. So I work with factories now and I beg them to take me on, and they take me on because they know me from the past, they know what I'm doing, they know $\mathrm{me}$, and at the end of the day everything is about relationships. Sales? All about relationships. Same with production. Relationships. (Designer X)

The importance of relationships in the fashion industry is covered in existing business literature. Relationships (including partnerships) provide a resource to any businessperson, and are particularly salient for those engaged with new ventures for which partnership and/or mentorship may open scores of opportunities, financial or other. As previously mentioned, a fortuitous encounter with an influential person can be the catalyst that launches a career. Emerging fashion designers frequently use their network for labor exchanges, expert advice, and -at times- financial assistance. Beyond finding a financial backer or business partner, other unique opportunities may arise from these supportive relationships.

I had a full Rolodex of people I could call [for advice]. I never thought business cards were important, but I called them up and asked for favors/ questions. People wondered why I didn't open in Paris, but here in NYC I know people; I know the factories, [I have the connections]. It's a form of mentorship. (Designer X)

Social Entrepreneurs have entrepreneurial skills and use these for social benefits. Although a key goal for a fashion business may be profitability within the competitive market, what lessons could small-scale designers learn from social entrepreneurship? What can the nonprofit sector teach future fashion entrepreneurs about the value of relationships? Social entrepreneurship is a less conventionally profit-oriented business model that may hold lessons for design entrepreneurs; one being that financial (brand) value can be added through building social and societal value. 
I want to have my own brand aesthetic and also the quality control. I don't want to be trapped in the world of wasting and cheap materials, including fast fashion. By going down the road of mass market and fast fashion, it kills the workers overseas and I don't believe that is humanely right. (Survey respondent)

One example of unconventional for-profit business practices is that of the shoe and eyewear brand Toms. Societal value is provided through the company's practice of donating a pair of shoes to a child in need for every pair sold and by providing eye care in under-developed countries through some of the profits derived from the sale of eyewear. This corporate responsibility has been praised as a model of social entrepreneurship while contributing to Toms' profitability. This approach is known as the "3BL," "TBL," or "triple bottom line" approach; the three pillars of this concept are social (people), environmental (planet), and economic (profit) success (Elkington, 1997).

How might a fashion start-up offer innovation through TBL business planning? A startup that is based locally in New York City could employ local merchants and sustain an industry that is endangered, local sourcing, production and distribution can also carry a lower carbon footprint. Many start-ups in New York City are accomplishing a form of TBL practice, yet few have made it an explicit part of their brand's ideology or identity. Fashion entrepreneurs working locally can look more broadly at the social impacts their business have, and embed this knowledge into their business plans with an eye toward achieving a triple bottom line.

\section{The New Collaborators}

Collaborations with profitable mainstream retailers, such as $H \& M$ and Target, are not socially entrepreneurial, but they can offer a mutually beneficial payoff. Although now commonplace in today's fashion industry, such collaborations were once considered damaging to one's brand. For example, when fashion designer Halston signed a license agreement with JC Penney in the early 1980's, his signature collection lost the support of his high-end customers and retailers. Similar reputational damage resulted when Pierre Cardin and Bill Blass over-extended their brands through licensing agreements.

The negative perception of "high-end" designers collaborating with "low-end" (or massmarket businesses) radically changed in 1995 when Isaac Mizrahi created the line IS ${ }^{\star \star} \mathrm{C}$, effacing his name to prevent "brand dilution" of his signature collection. Though not initially successful, the line gained enormous success in 2002 when re-launched and renamed Isaac Mizrahi for Target. Today, such well-known brands as Comme des Garçons, Karl Largerfeld, and Stella McCartney have created one-off collections with mass-retailers to sustain their own collections, while broadening their demographic base. Although not typical, collaborations have also been extended to less established brands, such as Rodarte and Prabal Gurung.

Creating a diffusion collection for a mass-market retailer holds distinct advantages for small, high-end designers; the retailer's complex supply chains and low-cost/high-volume 
manufacturing are not available to a start-up, high-end label that produces low volumes. These retailers assume the costs of manufacturing, holding inventory, and marketing; allowing the designer to gain tremendous access and -to a limited degree- a mass-market revenue stream. The high-end designer can take advantage of capacity s/he does not possess with the upside of accessing aspirational consumers who may become future customers for the designer's high-end collection. Financially, the rewards can be significant; for their collaborations with HÆM in 2005, Karl Lagerfeld and Stella McCartney were each reportedly paid \$1 million (Wilson, 2011).

However, not all designers wish to align or engage with the mass-market, as was the case of Designer X who -like many of our other respondents- described wanting to maintain exclusivity, prestige, and creative freedom for his high-end brand. For designers who are adverse to mass-market partnerships, what other methods will allow them to financially sustain their practice? What are the recommended priorities and strategies? Designer $\mathrm{X}$ enters collaborations with large mass-market brands, but he contributes his design work anonymously as a consultant.

Designer Y believes financial sustainability is the single most important objective for startups, whether the ultimate objective is monetary success or peer recognition; for professional goals that range from holding glamorous runway shows to acquiring leverage when entering lucrative business partnerships, the need for revenue is always essential. He states that start-up entrepreneurs must focus on two key elements for achieving reliable revenue through sales. The first is to prioritize the production of easily reproducible, low-cost and relatively high margin items that will allow a larger consumer demographic to access the brand. These products may also allow the brand to enter less competitive racks in less predictable locations. Offerings such as T-shirts, scarves, or even cell phone protectors, such as those designed by Kate Spade and Tory Burch, can achieve this goal.

The second key element is to access the lucrative accessories market. Designer Y estimates that Gucci's ratio of accessories-to-clothing is approximately $80 \%$ to $20 \%$; similar ratios are in evidence at apparel-associated brands such as Michael Kors. Evidence from the business literature (Choi, Liu, Tang, \& Yu, 2011) supports the assertion that young entrepreneurs should consider extending their product categories into accessories such as leather goods and eye wear. However, existing literature cautions that this is a high-risk, high-return endeavor as it involves entering a different market that has other established players. This strategy is more commonly implemented by European brands due to sluggish economic growth in Europe and hence the need to diversify a brand's sources of income. Evidence also points to the fact that high-end brands do more category extensions than massmarket brands, and successful high-end companies have tended to introduce category extensions early on, while mass-market brands introduce category extensions later in the brand's evolution.

For the fashion start-up, weighing the pros and cons of such strategies should be a consideration in the development of a business plan that diversifies the types and pricepoints of items. Once cash drivers have been established, they can be used to fund other less lucrative activities that build longer-term brand value. Establishing revenue-drivers such as these, in early stages of a brand's development, may help the designer survive long enough to become a recognized brand. 


\section{On capital: achieving personal and financial sustainability}

Young fashion entrepreneurs who start their business in today's economic environment face ever-increasing global competition; longevity of their enterprises is more of an accurate measure of performance than profitability (Murphy, Trailer, \& Hill, 1996). Established fashion businesses that typically have at least 150 employees and over $\$ 100$ million in yearly revenues (Ha-Brookshire \& Dyer, 2008) can compete by capitalizing on their reputation and brand name, as well as relying on their wide resource base and bargaining power over suppliers and customers. Fashion entrepreneurs, however, approach the same uncertain environment with a relative lack of resources and narrow networks. This makes the over-reliance of young entrepreneurs on "design" alone as a competitive advantage almost delusional; they instead should take more risks and be innovative in their products and business processes in order to survive (Garengo \& Bititci, 2005).

Without cash, an emerging business cannot survive long enough to become profitable. Rent, payroll, materials, labor, and advertising are just some aspects of owning a business that are reliant upon cash flow; the smaller the operation, the lower the designer's bargaining power over most of these aspects. Clearly a business with $\$ 100$ million plus annual revenue will not face cash flow problems. Rather than addressing cash flow, a topic extensively covered in existing business literature, this study focuses on financial sustainability, a more holistic strategy that also accounts for personal sustainability. Data collected in this study suggests that emerging graduates are starting small businesses with the goal of achieving personal fulfillment. However, one of our interviewees cautions that a designer must know him/herself, preferably before starting their own business:

I do think there are designers who want to be celebrities, there are those who want to be great designers, and there are others who just want to make money. Designers fall predominantly into these three buckets. (Designer Y)

For Designer Y, knowing what you want to get out of owning a business before starting one was one of his most important hindsight priorities. He felt the most overlooked goals are those that have little or nothing to do with design. In elaborating on the central question of "what makes me happy?" Designer Y acknowledged that for some this might be a runway show with press attention and enhanced visibility, while for others it could be the financial security that can provide winter vacations in the Caribbean. For Designer Y, the happiness question is not a design or business question; it precedes both, yet proceeds from both, and is vital to the creation of a sustainable business model. According to Designer $\mathrm{Y}$, this question only becomes more important over time because design recognition may come without financial success:

I began my small business with $\$ 5,000$, had runway shows during New York Fashion Week, received accolades from the press, yet I doubt I did more than one million [dollars] per year. The highest we had were six [employees] and lots of interns. I did so much myself, with lots of amazing help from people and we were able to "ride the wave."(Designer Y) 
In contrast to this, our younger respondents spoke of the desire to have their work seen and appreciated, and to do things on their own terms; similar responses were collected from the online survey and focus group. Lifestyle factors were a very secondary consideration, or a non-issue for these younger respondents. Although goals shift over time, it is advisable to take anticipated -and commonly held- life goals into consideration in the business planning process.

A lot of my life up to this point was always dreaming of having a business and now that I have a business I've realized that maybe actually that wasn't actually the biggest thing. A lot of the things I want for myself I still have to get them, in spite of the fact that I have this business. (Focus group respondent)

When one of this study's authors began teaching graphic design and typography eighteen years ago, his university would invite high-profile mid-career graphic designers to speak about their work to the students. As a partial consequence of this, many design graduates thought they would be entering the profession at a much higher level than their lack of professional experience indicated. Far from running their practice as a design laboratory to which select clients would be invited, they instead found themselves adjusting pixels as entry-level employees of larger design studios. How many of these students really knew what they would be doing as young designers?

This anecdote above illustrates two tendencies that are interrelated. The first is that pedagogical role-models exert a large influence on the way that young designers perceive themselves, and the second is that pedagogy can instill blindness toward alternate possibilities. There is a widely-held perception that a small business may offer young designers the ability to "do things on their own terms," unlike in the corporate world; this perception is often promoted by an undergraduate fashion pedagogy that emphasizes the designer's creative "voice." Paradoxically, this voice is usually nurtured in a pedagogical environment in which there is a deficit of relevant coursework to prepare graduating students to launch the smallscale fashion brands that may allow them more creative latitude.

The cash driver products previously mentioned provide ways in which designers can establish a financial base. The need for this is clear; according to Designer $Y$, a runway show in New York City costs between $\$ 150,000$ and $\$ 175,000$, and a one-time advertisement in Vogue can cost as much as $\$ 173,000$ (Vogue, 2013). This first category of expenses is luxuries to all but the most established brands. Start-up designers with limited financial resources need to gain publicity through social media, a web presence, or pop-up events, that they self-document or gain editorial exposure from; thus creating a greater potential "bang for their buck" than the use of mainstream media may provide.

A second category of expenses is somewhat within the designer's power to negotiate. Fashion models, for example, are often paid in clothes by young designers. If a designer only wholesales and sells online, rather than additionally operating retail stores, s/he avoids the costly overhead of renting and maintaining a store; acquiring one's own retail space was discouraged by Designer Y, particularly in locations with exorbitant rents as Manhattan. 
A third category of expenses are less negotiable, and they usually revolve around the materials and manufacturing of the garments and/or accessories; factories require either advance payment or a credit line.

For a start-up designer, the third season is typically regarded as "crunch time," the period beyond which the label needs to survive financially in order to be taken seriously as a semipermanent presence by magazines, reputable blogs, NY Fashion Week, and other arbiters of success. The third season is the hurdle one must pass due to the designer's need to front their costs while waiting for payment from retailers; if sufficient sales are generated by this third season, income and expenditures become aligned. Given this business aspect, the designer must decide what his/her starting resources and "burn rate will be; will they aim for a big, early "splash" or will they focus on surviving to the third season?

The third season's fiscal crunch can be mitigated by having an existing capital to sustain the business during this trial period, having a fortunate and successful first season, or creating other easily facilitated cash-drivers that contribute cash flow and the primary product. The designer may also focus marketing and sales around generating revenue (e.g. selling wholesale via the brand's website) and/or gain support through a "social entrepreneurship" strategy that allows the exchange of skills and services with friends and colleagues, thus decreasing costs. Two examples of this kind of community in New York City are Ourgoods (ourgoods.org) and Trade School (tradeschool.coop), both developed by artist and organizer Caroline Woolard.

In order for these strategies to succeed, several considerations must be made. To acquire sufficient capital, Designer Y strongly advocates for young designers to work with a financial partner and "sell part of your business right at the beginning." This strategy, he feels, will not only sustain the business financially, but it will also provide the necessary business mentorship for the young designer. Other designers - particularly several who have recently emerged in the New York industry- gain financial support and manufacturing connections through their families. Although sheer luck can be advantageous, it cannot truly be called a "business strategy." Building "social entrepreneurship" may be a successful way to combine both business planning and design due to peer support and collaboration. There are many factors that contribute towards sustaining an emerging fashion brand. When the designer decides what type of lifestyle he or she wishes to lead, priorities and business operations will be more easily defined and performed. To increase the chances of medium and long-term sustainability, designers must become increasingly educated in the alternate methods for raising capital. Unless the designer has large, personal financial reserves that allows for reliable cash flow, early alignment with a financial partner is recommended to provide both capital for the start-up and necessary business knowledge.

\section{Understanding Segments}

Fashion companies that achieved considerable success using business operation innovativeness include Zara; the company has managed to shift competition away from price and quality towards timing, rapid response, and flexibility in production 
(Richardson, 1996). H\&M on the other hand, introduced retail innovation that involved collaboration with luxury designers (Okonkwo 2007). We contend that success in sophisticated operations and management is probably a skill that is less attainable for a fashion start-up; without the capital, volume, or revenues to hire such expertise. Design entrepreneurs should focus on attainable and low cost strategies; one of these is gaining an understanding of market segments.

The fashion industry contains highly diverse markets. Many young designers - partly due to the influence of fashion pedagogy- are unaware of the opportunities within each unique market segment. This results in a marketplace dominated by pre-established and well-capitalized houses that utilize marketing as a business endeavor within their larger corporate operations, thus marginalizing young entrepreneurs. However, these segments, or "pies," are not difficult for the fashion entrepreneurs to understand, analyze, and design for.

Fashion brands are generally segmented into four clusters based on brand image and the associated price point and apparel mode (McDowell, 2006; Choi, et al., 2011). The cluster divisions divide along two spectra; premium brands versus mass brands, and fashion apparels versus basic apparels. Premium brands have a price point above $\$ 100$ for their secondary lines (ex: DKNY, Lauren by Ralph Lauren or Marc by Marc Jacobs) and above $\$ 1,000$ for their designer lines. Mass brands have a price point below $\$ 100$. "Fashion apparels" are smart or stylish, while "basic apparels" refer to informal or semi-sportswear. US brands in the "mass basic" cluster include Abercrombie \& Fitch, Gap, Levi's, Urban Outfitters and American Eagle Outfitters. There are no eminent "premium basic" US brands, the US market is currently served by European brands such as Diesel. "Premium fashion brands" encompass Calvin Klein, Donna Karan, Michael Kors, Anna Sui, and Ralph Lauren, while "mass fashion" is dominated by European brands such as Zara and H\&M. Designer X serves the small niche of high-end menswear and retails alongside such well established houses as Yohji Yamamoto and Comme des Garçons that offer menswear at similar price points; a tailored jacket from his collection costs approximately $\$ 1800$. Though relatively expensive, Designer X cited his apparel's competitive advantage of garment fit and finish, and his (labor-intensive) full canvassed jackets. This business strategy, based entirely on design and quality, targets male consumers who are either wealthy enough to afford such clothing or the rare fashion-forward consumer of modest means who prioritizes the acquisition of high quality and fashion-forward apparel. The combination of hindsight acquired by running his own high-end fashion business for fifteen years together with insights gained from his current work in the mass-market fashion business allowed Designer $\mathrm{Y}$ to understand the problems that most young designers face when focusing their businesses on the competitive high-end market segment. At the other end of the price-point spectrum are stores such as Walmart, in which Designer Y sees as a tremendous opportunity for designers to create better product.

Implicit in this discussion is whether prescribing a specific definition of "good design" may limit the young designer's professional goals. It also raises the questions of who defines good design, by what criteria, and what power does the discourse of good design (or "high design") have amongst young designers wishing to establish themselves? There is a counter-argument in favor of high design first and this centers on the need to obtain brand exposure. For many fashion designers, brand exposure relies heavily upon the 
media that favors fashion-forward work that will attract maximum viewers. This work tends to be runway fashion that is perceived to be "good design" due to this media promotion and accolades; media attention is, in effect, free advertising; essential for young entrepreneurs who do not have vast advertising budgets. In order to successfully attract this publicity, young designers must create interesting "media worthy" design that will then be showcased (free of charge) by the media. This approach can build significant brand equity very quickly and possible future licensing opportunities, but it is a strategy that carries considerable risk.

Designer Y underscored that many newly graduated design entrepreneurs perceive the mass-market as uncreative, despite comprising $80-90 \%$ of the overall consumer market. This ultimately creates a wealth of design opportunities within the mass market since few quality designers are eager to engage with it. Fashion entrepreneurs often miss the fact that "fashion is not all about style and continuous style change" (Unay \& Zehir, 2012) and "their chances of survival increase by exploring opportunities, aggressively pursuing their niche markets and delivering faster than larger firms" (Dean, Brown, \& Bamford, 1998). While the example of Designer X's high-end men's wear suggests that niche implies small and expensive, niche can also mean very specific product in a mass-market context, or being a very agile provider of a specialized product within a larger market segment.

In the retail setting, the advantages of the mass-market are noteworthy. Designer Y asserts the success of a fashion brand is often driven by "winning the real estate wars" through gaining access to limited rack space. Premium rack space, particularly in New York City and other urban centers, is in very short supply. However at suburban mass-market retailers, space is far more abundant and easier to obtain. He illustrates this problem in the following way:

Most stores are only 3,000-4,000 square feet. There are companies like Theory [that have high square footage in stores], but with a high-end brand like Jil Sander, you are only talking about fifteen square feet; she owns it and won't give it up to you. As a young designer, you are fighting for space with these big names, and that's a large retailer like Barneys! So now consider a [smaller] retailer like Holt Renfrew, where square footage is much smaller. The designer is working so hard on production, runway shows, selling, et cetera for what is really an arm-stretch of rack space. All this work so [the designer] can just say "I sold twenty five garment $s$ to this company." But walk into Walmart, Kohl's, Macy's, Dillard's, and Target. The space in incredible and so is the volume of product! But no one comes out of school and heads in that direction! They are all headed to runway show... together! (Designer Y) 


\section{Summary and conclusion}

For fashion design graduates who wish to launch their own small-scale practice, there is a deficit of business literature outside of the "self-help" variety and start-up designers consequently tend to use their local networks; this is a necessary but limited resource. Further, fashion entrepreneurs would benefit from acquiring broader perspectives outside of the design focus they are have been trained to have; this will provide an increased quantity of elements and strategies to increase their business' likelihood of survival.

We argued that perceived success can build consumer demand: scalability enhances social influence and drives sales and market penetration. This may be approached strategically through social media. Regardless of a brand's size, virtually all participants in this study cited the importance of relationships for mentorship, support, and financial opportunities when building their businesses. We highlighted social entrepreneurship, collaborations, and opportunities within market segments as three key areas for consideration. Finally, we explored strategies to increase cash flow, support operations, and drive growth.

We have identified opportunities for further research. These include an investigation of specific social media strategies that can support scalability. We are also interested in investigating the future of fashion design pedagogy, particularly its evolution from a long-held Bauhaus ideology toward a strategic design emphasis prioritizing innovation and interdisciplinary engagement. Finally, of particular importance for furthering our research into small-scale fashion business practices is the question of how globalization and its local antagonists negotiate the markets of the future.

\section{References}

Branson, R. (2012). Like a virgin: Secrets they won't teach you at business school. London: Virgin Books.

Choi, T-M., Liu, S-C., Tang, CS, \& Yu, Y. (2011). A cross-cluster and cross-region analysis of fashion brand extensions. Journal of the Textile Institute, 102 (10), 890-904.

Dean, T.J., Brown, R.L., \& Bamford, C.E. (1998). Differences in large and small firm responses to environmental context: strategic implications from a comparative analysis of business formations. Strategic Management Journal, 19, 709-728.

Elkington, J. (1997). Canibals with forks: The triple bottom line of 21st century business. Oxford: Capstone Publishing Ltd.

Garengo, P., Biazzo, S., \& Bititci, U.S. (2005). Performance measurement systems in SMEs: A review for a research agenda. International Journal of Management Review, 7, 25-47.

Ha-Brookshire, J. \& Dyer, B. (2008). Framing a descriptive profile of a transformed apparel industry: Apparel import intermediaries in the United States. Journal of Fashion Marketing and Management, 13 (2), 161-178.

Larocca, A. (2003, June 23). Two stylish. New York Magazine. Retrieved from http://nymag. com/nymetro/shopping/fashion/features/n_8809/ 
Loschek, I. \& Klose, S. (2007). Fashion shapes Europe. Culture Report Progress Europe, 1. Retrieved from http://www.ifa.de/pdf/kr/2007/kr2007_en.pdf

Marshall, T. (2009, January). Designing design education. Form, 224. Retrieved from http: //www.icograda.org/education/education/articles1397.htm

Murphy, G.B., Trailer, J.W., \& Hill, R.C. (1996). Measuring performance in entrepreneurship research. Journal of Business Research, 36, 47-67.

Okonkwo, U. (2007). Luxury fashion branding: trends, tactics, techniques, New York: Pelgrave Macmillan.

Parsons The New School for Design. (2011). Parsons The New School for Design career survey: Class of 2010. New York, NY: Office of Institutional Research.

Pink, D.H. (2005). A whole new mind: Why right-brainers will rule the future. New York: Riverhead Books.

Pinkerson, D. \& Levin, M. (Producers), \& Levin, M. (Director). (2009). Schmata: rags to riches to rags [Motion picture]. United States: Home Box Office Documentary Films.

Polegato, R. \& Wall, M. (1980). Information seeking by fashion opinion leaders and followers. Home Economics Research Journal, 8, 327-338.

Postrel, V. (2003). The substance of style. New York: HarperCollins Publishers.

Richardson, J. (1996). Vertical integration and rapid response in fashion apparel, Organization Science, 7, 400-412.

Save the Garment Center. (2012). Mission statement. Retrieved from http://savethegarmentcenter.org/about/

Salganik, M., Dodds, P., \& Watts, D. (20006, February). Experimental Study of Inequality and Unpredictability in an Artificial Cultural Market. Science, 311(5762), 854-856.

Seigel, L. (2011, May 8). Why fast fashion is slow death for the planet. The Guardian, 35.

Taleb, N. (2007). The black swan: The impact of the highly improbable. New York: Random House.

The Municipal Art Society of New York. (2011, October 14). Fashioning the future: NYC's garment district. Retrieved from http://mas.org/urbanplanning/garment-district/

Towers, J. (2005, July/August). Sustainable design. Print. Retrieve from http://www.europeanoutdoorgroup.com/downloads/sustainable-design/Sustainabledesign.pdf

Unay, F.G. \& Zehir, C. (2012). Innovation intelligence and entrepreneurship in the fashion industry, Procedia - Social and Behavioral Sciences, 41, 315-321.

Van Zandt, D. (2011). Inaugural Address. Retrieved from http://www.newschool.edu/lea dership/president/installation/

Vogue. (2013). Media press kit. [Data file]. Retrieved from http://www.condenast.com/ brands/vogue/media-kit/print/rates

Watts, D. (2007, April 15). Is Justin Timberlake a product of cumulative advantage? The New YorkTimesMagazine.Retrieved fromhttp://www.nytimes.com/2007/04/15/magazine /15wwlnidealab.t.html?pagewanted=all\&_r $=0$

Wilson, E. (2011, November 16). A marriage of economic convenience. The New York Times. Retrieved from http://www.nytimes.com/2011/11/17/fashion/designer-retailer-uni on-remains-lucrative.html?ref=fashion

Wolff, L., Rhee, J. (2009, May). Is design the new liberal arts? Re:D, 26(6), 9-13. 
Yu, W., Fan, J., Harlock, S.C., \& Ng, S.P. (Eds.) (2006). Innovation and technology of women's intimate apparel. Cambridge, England: Woodhead Publishing Limited.

Resumen: Los graduados en diseño de indumentaria se inclinan cada vez más por dirigir sus ambiciones profesionales hacia los pequeños emprendimientos empresariales en lugar de dedicarse a las tradicionales opciones de práctica corporativa. Estos empresarios de la moda deben comprometerse con el desarrollo empresarial y de gestión, habilidades que normalmente no requiere de diseñadores dentro del modelo de negocio de las empresas. ¿Cómo debería prepararse el empresario de la moda del futuro? ¿Qué conocimientos y habilidades se requieren para convertirse en un empresario de la moda? ¿Existe una desconexión entre lo que los emprendedores graduados en moda creen que necesitan saber y las prácticas que en realidad mejor los prepara para iniciar y mantener una empresa de diseño de moda? Los autores abordan el entrepreneurismo de la moda en Nueva York, discuten la logística de los mercados masivos globalizados y los desafíos actuales de la pedagogía del diseño de moda en relación a la preparación para incorporarse en el contexto mundial de la moda. Luego los autores destacan la tendencia contraria que se da en las empresas locales de pequeña escala. Finalmente se proponen estrategias generales dirigidas hacia el empresario de la moda que desea crear un negocio sostenible en pequeña escala en Nueva York.

Palabras clave: emprendedor incidental - emprendimientos creativos - emprendimientos de moda- estrategia de negocios de moda - moda y negocios - moda y sustentabilidad pedagogía de la moda.

Resumo: Os graduados em design de indumentária inclinam-se cada vez mais por dirigir suas ambições profissionais aos pequenos empreendedores empresariais em lugar de dedicar-se às tradicionais opções de prática corporativa. Estes empresários da moda devem comprometer-se com o desenvolvimento empresarial e de gestão, habilidades que normalmente não requer de designers dentro do modelo de negócio das empresas. Como deveria preparar-se o empresário da moda do futuro? Que conhecimentos e habilidades se requerem para converter-se num empresário da moda? Existe uma desconexão entre o que os empreendedores graduados em moda acreditam que necessitam saber e as práticas que em verdade melhor os prepara para iniciar e manter uma empresa de design de moda? Os autores abordam o entrepreneurismo da moda em Nova York, discutem a logística dos mercados massivos globalizados e os desafios atuais da pedagogia do design de moda em relação à preparação para incorporar-se no contexto mundial da moda. Depois, os autores destacam a tendência contrária que se da nas empresas locais de pequena escala. Finalmente, se propõem estratégias gerais dirigidas ao empresário da moda que deseja criar um negócio sostenível em pequena escala em Nova York.

Palavras chave: empreendedor incidental - empreendimento de moda - empreendimentos criativos - estratégia de negócios de moda - moda e negócios - moda e sustentabilidade pedagogia da moda. 